\title{
Mechanisms of $2^{\prime}$-deoxyguanosine toxicity in mouse $\mathbf{T}$-lymphoma cells with purine nucleoside phosphorylase deficiency and resistance to inhibition of ribonucleotide reductase by dGTP
}

\author{
Dah-Shuhn DUAN, ${ }^{*}$ Tadashi NAGASHIMA, $\dagger$ Takao HOSHINO, $\uparrow$ Frederic WALDMAN, $\ddagger$ \\ Katarzyna PAWLAK* and Wolfgang SADEE* $\S$ \\ * School of Pharmacy, $\dagger$ Brain Tumor Research Center of the Department of Neurological Surgery, \\ and $\ddagger$ Department of Laboratory Medicine, University of California, San Francisco, CA 94143, U.S.A.
}

\begin{abstract}
Purine nucleoside phosphorylase (PNP; EC 2.4.2.1) deficiency is thought to cause T-lymphocyte depletion by accumulation of dG and dGTP, resulting in feedback inhibition of ribonucleotide reductase (RR; EC 1.17.4.1) and hence DNA synthesis. To test for additional toxic mechanisms of dG, we selected a double mutant of the mouse T-lymphoma S-49 cell line, dGuo-L, which is deficient in PNP and partially resistant to dGTP feedback inhibition of RR. The effects of $\mathrm{dG}$ on dGuo-L cells (concn. causing $50 \%$ inhibition, $\mathrm{IC}_{50}=150 \mu \mathrm{M}$ ) were compared with those on the wild-type cells $\left(\mathrm{IC}_{50}=30 \mu \mathrm{M}\right)$ and the NSU-1 mutant with PNP deficiency only $\left(\mathrm{IC}_{50}=15 \mu \mathrm{M}\right)$. Fluorescence flow cytometry showed that equitoxic dG concentrations arrested wild-type and NSU-1 cells at the $G_{1}-S$ interface while allowing continued DNA synthesis in the S-phase, whereas the double mutant dGuo-L cells progressed through the cell cycle normally. dGuo-L cells accumulated high levels of dGTP in $\mathrm{G}_{1}$-phase, but not in S-phase cells, because of the utilization of dGTP for DNA synthesis and limited capacity to synthesize dGTP from dG. These results support the hypothesis that dG/dGTP toxicity occurs in the $G_{1}$-phase or at the $G_{1}-S$ interface. Failure of dG to arrest the double mutant dGuo-L cells at the $G_{1}-S$ interface allows these cells to escape into S-phase, with an accompanying drop in dGTP levels. Thus the partial resistance of dGuo-L cells to dG toxicity may result from their shorter residence time in $G_{1}$, allowing them to sustain higher dGTP levels. Hence RR inhibition by dGuo may not be the primary toxic mechanism in S-49 cells; rather, it may serve as an accessory event in $\mathrm{dG}$ toxicity by keeping the cells in the sensitive phase of the cell cycle. Among the possible targets of dG toxicity is RNA synthesis, which was inhibited at an early stage in dGuo-L cells.
\end{abstract}

\section{INTRODUCTION}

An inborn deficiency of purine nucleoside phosphorylase (PNP; EC 2.4.2.1) results in severe immunodeficiency that is characterized by marked T-lymphocyte depletion and normal Blymphocyte functions [1,2], in contrast with a combined severe immunodeficiency caused by adenosine deaminase deficiency, in which both B- and T-lymphocyte functions are affected [3,4]. Whereas multiple mechanisms have been reported for ADA deficiency ([5] and refs. therein), the predominant cause of Tlymphocyte toxicity in PNP deficiency is thought to be the accumulation of dG and its metabolite, dGTP [6,7], which causes feedback inhibition of ribonucleotide reductase (RR; EC 1.17.1) activity towards CDP [5,8] and enhances ADP reduction [9]. The selectivity of dG cytotoxicity against $\mathrm{T}$ lymphocytes may rest in the ability of these cells to trap dGTP inside the cell by high kinase and low nucleotidase activities $[10,11]$. dGuo and its analogues are therefore considered to be potential chemotherapeutic agents for leukaemias [12]. However, the hypothesis of RR inhibition by dGTP failed to explain the early toxicity caused by rather high dG levels before initiation of DNA synthesis in concanavalin-A-stimulated murine spleen Tlymphocytes [13], the selective sparing of $T$ helper cell activity required for normal B-lymphocyte function [14,15], or the inability of deoxycytidine to reverse dG effects on phytohaemagglutinin-stimulated human peripheral blood lymphocytes $[11,16]$. Finally, several studies on $\mathrm{dG}$ toxicity were performed in cells with normal PNP activity, allowing for $\mathrm{dG}$ conversion to guanine and subsequent guanine toxicity (e.g. $[8,17])$. Therefore the purpose of this study is to address additional mechanisms of dG that may have implications in its immunological effects and cytotoxicity.

To investigate cytotoxic effects of $\mathrm{dG}$ that are independent of feedback inhibition of RR, we selected a mouse T-lymphoma cell line, dGuo-L [18]. This double-mutant of the parent S-49 mouse cells is devoid of PNP and heterozygous for an RR allele resistant to dGTP feedback regulation [18]. The results were compared with those obtained in the parent S-49 wild-type cells and in PNP-deficient mutant cells from which the mechanism involving RR inhibition was derived [5]. Our results suggest that $R R$ inhibition may not be the primary mechanism of $d G$ toxicity against S-49 cells, but rather serves to maintain cells in the sensitive phase, $G_{1}$ or $G_{1}-S$ interphase, of the cell cycle.

\section{MATERIALS AND METHODS}

\section{Materials}

5-Bromodeoxyuridine ( $\mathrm{BrdU})$, chromomycin $\mathrm{A}_{3}$, dG, $N^{6}, 2^{\prime}-$ $O$-dibutyl cyclic AMP $\left(\mathrm{Bt}_{2} \mathrm{cAMP}\right)$, ethidium bromide, Freon (1,1,2-trichloro-1,2,2-trifluoroethane), iodoacetic acid, propidium iodide, proteinase $\mathrm{K}$, tri-n-octylamine, Tris buffer and Triton X-100 were purchased from Sigma Chemical Co., St. Louis, MO, U.S.A. $\left[{ }^{3}{ }^{3} \mathrm{H}\right]$ Cytidine $\left.\left({ }^{3} \mathrm{H}\right] \mathrm{C}, 23 \mathrm{Ci} / \mathrm{mmol}\right)$, $[8-$ $\left.{ }^{3} \mathrm{H}\right] \mathrm{dG}(7.4 \mathrm{Ci} / \mathrm{mmol})$, [8-14 $\left.\mathrm{C}\right]$ guanine $\left(\left[{ }^{14} \mathrm{C}\right] \mathrm{Gua}, 57 \mathrm{mCi} / \mathrm{mmol}\right)$, $\left[2,3,4,5-{ }^{3} \mathrm{H}\right]$ leucine $(19 \mathrm{Ci} / \mathrm{mmol}),\left[\right.$ methyl $\left.-{ }^{3} \mathrm{H}\right] \mathrm{dT}(80 \mathrm{Ci} / \mathrm{mmol})$, and $\left[5-{ }^{3} \mathrm{H}\right]$ uridine $\left(\left[{ }^{3} \mathrm{H}\right] \mathrm{U}, 23 \mathrm{mCi} / \mathrm{mmol}\right)$ were purchased from ICN Pharmaceutical Inc., Irvine, CA, U.S.A. Mouse antiBrdUrd antibody was kindly supplied by Dr. Joe Gray, National

\footnotetext{
Abbreviations used: BrdU, 5'-bromodeoxyuridine; $\mathrm{Bt}_{2} \mathrm{CAMP}, N^{6}, 2^{\prime}$-O-dibutyl cyclic AMP; $\left[{ }^{14} \mathrm{C}\right] \mathrm{Gua},\left[8-{ }^{14} \mathrm{C}\right]$ guanine; $\mathrm{IC}_{50}$, concentration causing $50 \%$ inhibition; PBS, phosphate-buffered saline; PNP, purine nucleoside phosphorylase; RR, ribonucleotide reductase.

$\S$ To whom correspondences should be addressed.
} 
Lawrence Livermore Laboratory, Livermore, CA, U.S.A. Vanadyl-ribonucleotide complex was purchased from BRL Life Technology, Gaithersburg, MD, U.S.A. SDS, electrophoresisgrade agarose and urea were purchased from Bio-Rad Laboratories, Richmond, CA, U.S.A. All other reagents were of analytical grade.

\section{Cell culture}

S-49 wild-type, NSU-1 (PNP-deficient) mutant and dGuo-L mutant cells were cultured in Dulbecco's modified Eagle's medium with $10 \%$ heat-inactivated horse serum at $37^{\circ} \mathrm{C}$ in $10 \%$ $\mathrm{CO}_{2}$. The growth characteristics of these cells have been described elsewhere [18]. For growth experiments, dG was added to exponentially growing cells $\left(5 \times 10^{5} / \mathrm{ml}\right)$ for $24 \mathrm{~h}$. Cell counts were then determined with a Coulter counter model $Z_{r}$. For $G_{1}$ phase enrichment, S-49 cells were incubated with $500 \mu \mathrm{M}$ $\mathrm{Bt}_{2} \mathrm{cAMP}$ for $24 \mathrm{~h}$ and washed with phosphate-buffered saline (PBS ; $10 \mathrm{~mm}$-sodium phosphate, $120 \mathrm{~mm}-\mathrm{NaCl}$ and $2.7 \mathrm{~mm}-\mathrm{KCl}$, pH 7.4) immediately before experiments. S-phase-enriched cell populations were obtained $24 \mathrm{~h}$ after washing of $\mathrm{Bt}_{2} \mathrm{cAMP}$.

\section{Deoxyribonucleotide pool determination}

S-49 cells incubated with dG for $4 \mathrm{~h}$ were harvested and washed with ice-cold PBS. Ice-cold $\mathrm{HClO}_{4}$ was added to the cells, and the supernatant was extracted with a mixture of Freon and tri-n-octylamine $(78: 22, \mathrm{v} / \mathrm{v})$. The aqueous extract was analysed by h.p.l.c. for nucleotide contents using a linear gradient solvent system of $0.02 \mathrm{M}-\mathrm{NH}_{4} \mathrm{H}_{2} \mathrm{PO}_{4}$ in $0.01 \mathrm{M}-\mathrm{KCl}$, pH 3.6 (buffer A) and $1.0 \mathrm{M}-\mathrm{NH}_{4} \mathrm{H}_{2} \mathrm{PO}_{4}$ in $0.5 \mathrm{M}-\mathrm{KCl}, \mathrm{pH} 3.6$ (buffer B), starting with $100 \% \mathrm{~B}$ in $20 \mathrm{~min}$ at a flow rate of $2.0 \mathrm{ml} / \mathrm{min}$. External standards of $2-5 \mu \mathrm{mol}$ of each nucleotide were used for quantification. Fractions of $0.6 \mathrm{ml}$ were collected for the desired peaks and assayed for radioactivity by scintillation counting [19].

\section{DNA, RNA and protein synthesis determination}

Cells growing logarithmically $\left(\sim 5 \times 10^{5} / \mathrm{ml}\right)$ were incubated with $\mathrm{dG}$ and $1 \mu \mathrm{Ci} / \mathrm{ml}$ concentrations $\left[{ }^{3} \mathrm{H}\right] \mathrm{C},\left[{ }^{3} \mathrm{H}\right] \mathrm{dT},\left[{ }^{3} \mathrm{H}\right] \mathrm{U}$ or $\left[{ }^{14} \mathrm{C}\right] \mathrm{Gua}$, in combination with $\left[{ }^{3} \mathrm{H}\right] \mathrm{dG}$, for $4 \mathrm{~h}$ at $37^{\circ} \mathrm{C}$. After washing with $\mathrm{PBS}$, pellets were precipitated with ice-cold $\mathrm{HClO}_{4}$ $(0.4 \mathrm{M})$, washed twice with $\mathrm{HClO}_{4}$ and digested with $0.3 \mathrm{M}-\mathrm{KOH}$ overnight [20]. Counts in the final $\mathrm{HClO}_{4}$ precipitate and in the supernatant represent incorporation of tracers into DNA and RNA respectively.

For protein synthesis measurement, cells were incubated with $\mathrm{dG}$, and $\left[{ }^{3} \mathrm{H}\right] \mathrm{Leu}(1 \mu \mathrm{Ci} / \mathrm{ml})$ was added $2 \mathrm{~h}$ before harvest. The $\mathrm{HClO}_{4}$ pellets were washed and then harvested on GF-B filter paper followed by three washes with ice-cold $\mathrm{HClO}_{4}$.

\section{Cell cycle analysis}

Cell suspensions containing approx. $10^{6}$ cells were centrifuged and fixed in $1 \mathrm{ml}$ of $70 \%$ ethanol and stored at $4{ }^{\circ} \mathrm{C}$ overnight. Cells were then harvested and stained with chromomycin $\mathrm{A}_{3}$ $(17 \mu \mathrm{M})$ solution containing $\mathrm{MgCl}_{2}(0.015 \mathrm{M})$ for $1 \mathrm{~h}$ before analysis on a 5-W argon-laser FACSIII flow cytometer (BectonDickinson, Sunnyvale, CA, U.S.A.) at $457 \mathrm{~nm}$ [21].

For BrdU/propidium iodide dual staining, a modified procedure according to Dolbeare et al. [22] was used. Briefly, cells were pulsed with a subtoxic concentration of $\operatorname{BrdU}(10 \mu \mathrm{M})$ for $30 \mathrm{~min}$ to label the DNA of S-phase cells, and then incubated with dG. Harvested cells $\left(\sim 5 \times 10^{6}\right)$ were fixed in ethanol and resuspended in $1.5 \mathrm{ml}$ of cold $\mathrm{HCl}(0.1 \mathrm{M})$ containing $0.7 \%$ Triton X-100. Cells were pelleted, and DNA was denatured by incubating with $2.4 \mathrm{M}-\mathrm{HCl}$ at room temperature for $20 \mathrm{~min}$. After washing with buffer (0.5\% Tween 20 in PBS), $500 \mu \mathrm{l}$ of mouse anti-BrdU antibody (IU:4, diluted $1: 4000$ in PBS $/ 0.5 \%$ Tween $20 / 0.5 \%$ BSA) was added to the cells and incubated for
$30 \mathrm{~min}$ at room temperature. A second antibody, fluorescein isothiocyanate-conjugated goat anti-mouse $\operatorname{IgG}$ antibody, was added for $20 \mathrm{~min}$. Washed pellets were then stained with $1 \mathrm{ml}$ of propidium iodide $(10 \mu \mathrm{g} / \mathrm{ml}$ in PBS) for $30 \mathrm{~min}$, syringed through a single-cell nylon mesh $(22 \mu \mathrm{m})$ and analysed directly using a dual-laser FACSII flow cytometer. To compare the rates at which BrdU-labelled control and dG-treated cells progress through the cell cycle, the percentage of BrdU-labelled cells in the $G_{1}-, S-$, and $G_{2} / M$-phases at different sampling times was calculated as described [22]. Further, DNA synthesis time $\left(T_{\mathrm{s}}\right)$ was also calculated for both control and dG-treated cells at different times of sampling, as previously described by Begg et al. [23].

\section{RNA synthesis in cell homogenates}

Exponentially growing dGuo-L cells were harvested by centrifugation, washed twice with cold PBS and resuspended in a buffer containing $150 \mathrm{~mm}$-sucrose, $80 \mathrm{~mm}-\mathrm{KCl}, 35 \mathrm{~mm}$-Hepes,

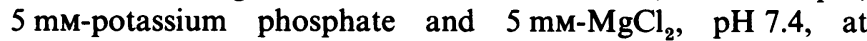
$2 \times 10^{8}$ cells $/ \mathrm{ml}$. Portions of the cell suspension $(0.8-1 \mathrm{ml})$ were homogenized with a Brunsmith Ultrasonic cell disrupter (micro tip) with 60 pulses ( $20 \%$ active cycle) at power output level 2. Cell homogenate $(25 \mu \mathrm{l})$ was added to $75 \mu \mathrm{l}$ of reaction mixture in a buffer containing $50 \mathrm{mM}$-Hepes, $7.5 \mathrm{~mm}$-potassium

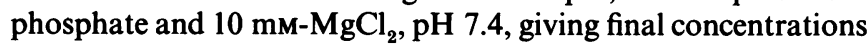
of $1 \mathrm{~mm}$-dithiothreitol, $0.5 \mathrm{~mm}$-ATP, -CTP and -UTP, and $0.1 \mathrm{~mm}-\left[{ }^{3} \mathrm{H}\right] \mathrm{GTP}$ (specific radioactivity 222 d.p.m./pmol). Alternatively, 1 mm-dithiothreitol, 0.5 mM-ATP, -CTP and -GTP and $0.1 \mathrm{mM}-\left[{ }^{3} \mathrm{H}\right] \mathrm{UTP}$ were used. The reaction mixture was supplemented with 0-2.5 mM-dGTP or -dATP and incubated at $37^{\circ} \mathrm{C}$ for 1-60 min. RNA- or polynucleotide-bound radioactivity was determined as described [24].

\section{Isolation and electrophoresis of cytoplasmic RNA}

$\left[{ }^{3} \mathrm{H}\right] \mathrm{Gua}$-labelled cells were washed with ice-cold PBS and resuspended in iced lysis buffer $\mathrm{C}$ (10 mM-Tris, pH 7.0, $10 \mathrm{~mm}$ $\mathrm{NaCl}, 0.2 \%$ Triton X-100, $1 \%$ ethanol and 100 mM-vanadylribonucleotide complex). The mixture was vortex-mixed and kept on ice for $10 \mathrm{~min}$. After centrifugation, the supernatant (containing cytoplasmic RNA) was removed, and 0.2 vol. of lysis buffer D (100 mM-Tris/HCl, $50 \mathrm{~mm}$-EDTA and $10 \%$ SDS, $\mathrm{pH}$ 7.1) was added. The solution was incubated with proteinase $\mathrm{K}$ (final concentration $200 \mu \mathrm{g} / \mathrm{ml}$ ) at $37^{\circ} \mathrm{C}$ for $30 \mathrm{~min}$ followed by three extractions with phenol/chloroform/isoamyl alcohol (25:24:1, by vol.). Extracted cytoplasmic RNA was stored in $100 \%$ ethanol containing $0.2 \mathrm{M}-\mathrm{NaCl}$ at $-20^{\circ} \mathrm{C}$ overnight before analysis. Electrophoresis of $\left[{ }^{3} \mathrm{H}\right] \mathrm{RNA}$ was performed using vertical $1.5 \%$ agarose gels containing $6 \mathrm{M}$-urea and $0.015 \mathrm{M}$ iodoacetate in a TPE running buffer $(0.04 \mathrm{M}$-Tris, $0.036 \mathrm{M}$ $\mathrm{NaH}_{2} \mathrm{PO}_{4}$, and $0.001 \mathrm{~m}-\mathrm{EDTA}, \mathrm{pH}$ 7.4) at constant voltage $(40 \mathrm{~V})$ for $12 \mathrm{~h}$. RNA bands were then revealed by staining with ethidium bromide. Incorporation of ${ }^{3} \mathrm{H}$ into different size classes of RNA was determined by fractionation of the gels and liquid scintillation counting of the gel slices.

\section{RESULTS}

\section{Inhibition of S-49 cell growth by dG}

Over a 24-h incubation, dG inhibited growth of wild-type S49, PNP-negative (NSU-1) and the double-mutant (dGuo-L) cells, with $\mathrm{IC}_{50}$ values (concns. causing $50 \%$ inhibition) of $\sim 30 \mu \mathrm{M}, 15 \mu \mathrm{M}$ and $150 \mu \mathrm{M}$ respectively. These results were similar to values reported by Ullman et al. [18], who attributed the lower sensitivity of dGuo-L cells to a partial loss of feedback inhibition of RR by dGTP. 


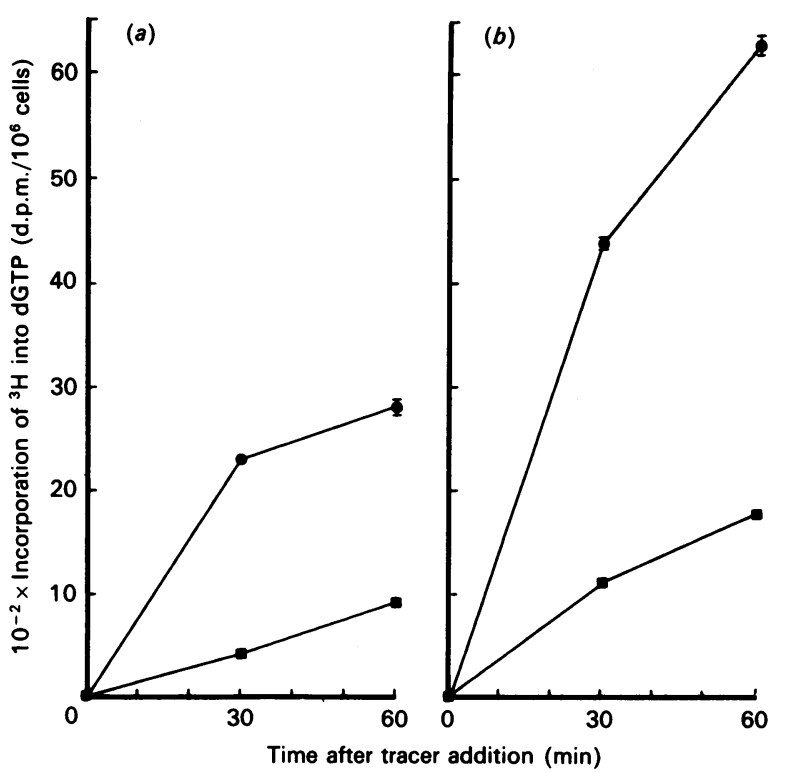

Fig. 1. dGTP accumulation in synchronized S-49 cells

To yield $\mathrm{G}_{1}$-phase cells $(\bigcirc)$, PNP-deficient mutant (NSU-1, $a$ ) and the double-mutant (dGuo-L, b) cells were synchronized using $\mathrm{Bt}_{2}$ cAMP $(0.5 \mathrm{mM})(95 \%$ and $92 \%$ respectively). S-phase-enriched cell populations $(\square)(58 \%$ and $64 \%$ respectively) were also obtained. The cells were labelled with $\left[{ }^{3} \mathrm{H}\right] \mathrm{dG}(1 \mu \mathrm{Ci} / \mathrm{ml})$ for only $1 \mathrm{~h}$ to minimize changes in cell-cycle distribution. Incorporation of ${ }^{3} \mathrm{H}$ into dGTP was measured by h.p.l.c. after harvesting. Each point represents the mean of duplicates \pm S.D.

\section{Accumulation of dGTP from dG by dGuo-L cells}

In order to test whether the less sensitive dGuo-L cells accumulate dGTP when exposed to $\mathrm{dG}$, dGTP pools were measured by h.p.l.c. After 4-h incubations, dGTP levels in dGuoL cells increased by $3-5$-fold with low dG concentrations $(25 \mu \mathrm{M})$ and up to 15 -fold at $300 \mu \mathrm{M}$-dGuo, compared with controls (for detailed kinetic studies, see [25]). The accumulation of dGTP by dGuo-L cells was similar to or exceeded by up to 2-fold the dGTP accumulation in wild-type and PNP-deficient cells. The partial resistance of dGuo-L cells was therefore not associated with failure to phosphorylate dG to dGTP.

\section{Failure of dGTP accumulation in S-phase cells}

The kinetics of $\left[{ }^{3} \mathrm{H}\right] \mathrm{dGTP}$ were then studied in partially synchronized S-49 cells. After treatment with $0.5{\mathrm{mM}-\mathrm{Bt}_{2} \mathrm{cAMP}}^{\mathrm{c}}$ for $24 \mathrm{~h}, \mathrm{~S}-49$ wild-type, NSU-1 and dGuo-L cells were synchronized at the $G_{1}$-phase ( $>95 \%$ ) of the cell cycle. These cells were then released from $G_{1}$-phase by resuspension in fresh medium, and S-phase-enriched cells (50-60\% of cells in S-phase, determined by flow cytometry) were obtained $24 \mathrm{~h}$ later [26]. When $G_{1}$-phase or S-phase-enriched S-49 wild type cells were labelled with $\left[{ }^{3} \mathrm{H}\right] \mathrm{dG}$ tracer, ${ }^{3} \mathrm{H}$ activity was found primarily in GTP, as a result of high PNP activity. In contrast, $\left[{ }^{3} \mathrm{H}\right] \mathrm{dG}$ predominantly labelled the dGTP pool of the PNP-deficient mutants, i.e. NSU-1 and dGuo-L cells, which is expected from lack of metabolic conversion of the tracer to $\left[{ }^{3} \mathrm{H}\right] \mathrm{Gua}$ (see also [25]). Surprisingly, however, $\left[{ }^{3} \mathrm{H}\right] \mathrm{dG}$ labelled the dGTP pool up to 3-fold more efficiently in $\mathrm{G}_{1}$-phase- than in S-phase-enriched cells (Fig. 1).

These results suggested that $G_{1}$-phase cells preferentially accumulate high dGTP levels when exposed to dG, whereas dGTP accumulation is prevented in S-phase because of ongoing DNA synthesis. Therefore the dGTP pool expansion by $d G$
(50 $\mu \mathrm{M}$, plus $1 \mu \mathrm{Ci}$ of $\left[{ }^{3} \mathrm{H}\right] \mathrm{dG}$ for $1 \mathrm{~h}$ ) was tested by h.p.l.c. in synchronized dGuo-L cells. The dGTP pool size in $\mathrm{G}_{1}$-phase cells increased from $\sim 0.8 \mathrm{nmol} / 10^{8}$ cells in the control to $\sim 8.5 \mathrm{nmol} / 10^{8}$ cells, and the measured specific radioactivity of dGTP was identical to that of $\left[{ }^{3} \mathrm{H}\right] \mathrm{dG}$ added to the medium. In contrast, S-phase-enriched $(55 \%)$ dGuo-L cells reached a dGTP pool of only $\sim 3.5 \mathrm{nmol} / 10^{8}$ cells, with a specific radioactivity of $\left[{ }^{3} \mathrm{H}\right] \mathrm{dGTP}$ only $45 \%$ of that of the added $\left[{ }^{3} \mathrm{H}\right] \mathrm{dG}$. Similar experiments with NSU-1 cells confirmed the 2-3-fold lower pool sizes of dGTP in S-phase-enriched compared with $G_{1}$-phase cells. The tracer dilution in the dGTP pool indicates that unlabelled dGTP was formed from unlabelled GDP precursors via RR, which is active in S-phase but not in $G_{1}$-phase cells [26]. If one further considers the presence of approx. $45 \%$ labelled $G_{1}$-phase cells in the S-phase-enriched cell population, it becomes clear that $S$-phase cells accumulated negligible amounts of $\left[{ }^{3} \mathrm{H}\right] \mathrm{dG}$ into dGTP and that the overall dGTP pool size remained rather small.

\section{DNA and RNA synthesis by $\mathrm{S}-49$ cells}

Because dG can cause perturbations of nucleotide metabolism, we used several radioactive tracers to assess the effects of $\mathrm{dG}$ on DNA and RNA synthesis by S-49 cells. After $4 \mathrm{~h}$ of incubation, $\left[{ }^{3} \mathrm{H}\right] \mathrm{dT}$ incorporation was slightly decreased by $\mathrm{dG}$ in wild-type cells $(60 \mu \mathrm{M}, 95 \%$ of control) and NSU-1 cells $(40 \mu \mathrm{M}, 67 \%$ of control). Longer incubation periods up to $12 \mathrm{~h}$ further decreased $\left[{ }^{3} \mathrm{H}\right] \mathrm{dT}$ incorporation to around $30 \%$ of the control, followed by partial recovery at $24 \mathrm{~h}$ ( $\sim 50 \%$ of control) in both cell lines. In contrast, $\left[{ }^{3} \mathrm{H}\right] \mathrm{dT}$ incorporation into the DNA of dGuo-L cells was actually enhanced by $\mathrm{dG}$ (up to 2.5 -fold at $350 \mu \mathrm{M}$ ), which can be attributed to changes in dTTP turnover; however, these results argue against a drastic inhibition of DNA synthesis in dGuo-L cells. $\left[{ }^{3} \mathrm{H}\right] \mathrm{C}$ was then used to label both RNA and DNA, the latter involving the RR-mediated conversion of CDP to dCDP (Table 1). Again, there was only a rather small reduction of $\left[{ }^{3} \mathrm{H}\right] \mathrm{C}$ incorporation into DNA in the dGuo-L cells. In contrast, $\left[{ }^{3} \mathrm{H}\right] \mathrm{C}$ labelling of DNA was more strongly decreased by dG in S-49 wild-type and NSU-1 mutant cells. Although the fall to $30 \%$ of control DNA labelling suggests inhibition of DNA synthesis, one might have expected a stronger inhibition of tracer incorporation if accumulated dGTP strongly inhibits RR. Apparently, residual RR activity and DNA synthesis continued over at least $4 \mathrm{~h}$ of $\mathrm{dG}$ exposure. The incorporation of both $\left[{ }^{3} \mathrm{H}\right] \mathrm{C}$ and $\left[{ }^{3} \mathrm{H}\right] \mathrm{U}$ into the RNA of dGuo-L cells indicated depression $(\sim 50 \%)$ of RNA synthesis in all three cell lines (Table 1).

To validate the effects of dG on DNA and RNA synthesis by dGuo-L cells, simultaneous incorporation of $\left[{ }^{3} \mathrm{H}\right] \mathrm{dG}$ and $\left[{ }^{14} \mathrm{C}\right]$ Gua into DNA and RNA was measured. dGuo-L cells were incubated for $4 \mathrm{~h}$ with $10 \mu \mathrm{M}$-mycophenolic acid (to inhibit inosine $5^{\prime}$-monophosphate dehydrogenase), $200 \mu \mathrm{M}-\left[{ }^{14} \mathrm{C}\right] \mathrm{Gua}$ (to maintain $>90 \%$ normal DNA synthesis) [25], and various concentrations of $\left[{ }^{3} \mathrm{H}\right] \mathrm{dG}$. Mycophenolic acid served to prevent any formation of guanine nucleotides de novo, and high concentrations of the diluted tracer $(1 \mu \mathrm{Ci} / \mathrm{ml}$ of each) were chosen to minimize further dilution by endogenously preformed guanine nucleotides. Subsequent experiments showed that the presence of mycophenolic acid had little effect on tracer flux and incorporation, since the addition of $200 \mu \mathrm{M}$-Gua was sufficient to fully suppress GMP formation de novo. Control experiments with $\left[{ }^{14} \mathrm{C}\right]$ Gua $(200 \mu \mathrm{M})$ in $4 \mathrm{~h}$ incubations gave DNA synthesis rates similar to the calculated absolute rate of $\sim 9 \mathrm{nmol} \mathrm{dG} / 30 \mathrm{~min}$ per $10^{8}$ cells for $S-49$ cells [27]. Calculations of the sum of $\mathrm{dG}$ and Gua incorporated into DNA and RNA, on the basis of specific radioactivities of the added tracers, showed that the rate of DNA synthesis was not affected in dGuo-L cells by increasing con- 
Table 1. Effects of dG on the incorporation of $\left[{ }^{3} \mathrm{H}\right] \mathrm{dT},\left[^{3} \mathrm{H}\right] \mathrm{U}$ and $\left[^{3} \mathrm{H}\right] \mathrm{C}$ into dGuo-L-cells

Cells were incubated with dG together with $\left[{ }^{3} \mathrm{H}\right] \mathrm{dT}$ and $\left[{ }^{3} \mathrm{H}\right] \mathrm{U}$ for $4 \mathrm{~h}$, or labelled with $\left[{ }^{3} \mathrm{H}\right] \mathrm{C}$ for $1 \mathrm{~h}$ after a $4 \mathrm{~h}$ incubation with dG before harvesting. DNA and RNA were separated and radioactivity determined. Results are means \pm S.D., $n=2$.

\begin{tabular}{|c|c|c|c|c|c|c|c|c|c|}
\hline \multirow{3}{*}{$\begin{array}{l}{[\mathrm{dG}]} \\
(\mu \mathrm{M})\end{array}$} & \multicolumn{3}{|c|}{ dGuo-L cells } & \multirow{2}{*}{\multicolumn{3}{|c|}{$\begin{array}{c}\text { Wild-type cells } \\
\begin{array}{c}{\left[5-{ }^{3} \mathrm{H}\right] \mathrm{C} \text { incorporation }} \\
(\% \text { of control }\end{array}\end{array}$}} & \multirow{2}{*}{\multicolumn{3}{|c|}{$\begin{array}{c}\text { PNP-deficient cells } \\
\begin{array}{c}{\left[5-{ }^{3} \mathrm{H}\right] \mathrm{C} \text { incorporation }} \\
(\% \text { of control })\end{array}\end{array}$}} \\
\hline & \multirow{2}{*}{$\begin{array}{c}{\left[5-^{3} \mathrm{H}\right] \mathrm{U} \text { incorporation }} \\
\text { into RNA } \\
(\% \text { of control })\end{array}$} & \multicolumn{2}{|c|}{$\begin{array}{c}{\left[5-{ }^{3} \mathrm{H}\right] \mathrm{C} \text { incorporation }} \\
\text { (\% of control) }\end{array}$} & & & & & & \\
\hline & & DNA & RNA & $\begin{array}{l}{[\mathrm{dG}]} \\
(\mu \mathrm{M})\end{array}$ & DNA & RNA & $\begin{array}{l}{[\mathrm{dG}]} \\
(\mu \mathrm{M})\end{array}$ & DNA & RNA \\
\hline $\begin{array}{r}0 \\
25 \\
50 \\
100 \\
200 \\
350\end{array}$ & $\begin{array}{r}100 \pm 6 \\
93 \pm 1 \\
87 \pm 1 \\
70 \pm 4 \\
64 \pm 1 \\
49 \pm 1\end{array}$ & $\begin{array}{r}100 \pm 1 \\
104 \pm 5 \\
96 \pm 1 \\
90 \pm 6 \\
77 \pm 1 \\
69 \pm 3\end{array}$ & $\begin{array}{r}100 \pm 2 \\
89 \pm 4 \\
84 \pm 3 \\
75 \pm 1 \\
67 \pm 2 \\
54 \pm 1\end{array}$ & $\begin{array}{r}0 \\
10 \\
20 \\
35 \\
60 \\
100\end{array}$ & $\begin{array}{r}100 \pm 2 \\
82 \pm 3 \\
65 \pm 4 \\
47 \pm 7 \\
37 \pm 6 \\
26 \pm 5\end{array}$ & $\begin{array}{r}100 \pm 1 \\
86 \pm 7 \\
78 \pm 6 \\
76 \pm 8 \\
62 \pm 6 \\
65 \pm 5\end{array}$ & $\begin{array}{r}0 \\
10 \\
20 \\
40 \\
80\end{array}$ & $\begin{array}{r}100 \pm 3 \\
80 \pm 4 \\
64 \pm 2 \\
52 \pm 4 \\
36 \pm 2\end{array}$ & $\begin{array}{r}100 \pm 1 \\
71 \pm 2 \\
61 \pm 2 \\
59 \pm 5 \\
-\end{array}$ \\
\hline
\end{tabular}

centrations of dG up to $350 \mu \mathrm{M}$, whereas RNA synthesis declined sharply between 50 and $100 \mu \mathrm{M}$-dGuo (Fig. 2). The specific ${ }^{14} \mathrm{C}$ radioactivity of the GTP pool (from $\left[{ }^{14} \mathrm{C}\right] \mathrm{Gua}$ ), measured after $4 \mathrm{~h}$ of incubation, slightly decreased with increasing dG concentrations in the medium. However, the decrease in specific ${ }^{14} \mathrm{C}$ radioactivity was at most $25 \%$, and therefore did not account for the fall in RNA tracer incorporation. Further, the lower ${ }^{14} \mathrm{C}$ specific radioactivity of GTP was compensated for by considering the small contribution of ${ }^{3} \mathrm{H}$ from $\mathrm{dG}$ that also entered the GTP pool (by the $\sim 5 \%$ residual PNP activity in dGuo-L cells). Hence dG caused a sizeable fall in RNA synthesis in dGuo-L cells, but it had no effect on DNA synthesis.

\section{RNA synthesis in dGuo- $L$ cell homogenates}

In order to determine any effect of dGTP, and for comparison, of dATP, on RNA polymerase, the activity of this enzyme was determined in cell homogenates in the presence of the four ribonucleotides and dGTP or dATP. No consistent inhibition of RNA polymerase by dGTP or dATP was observed. Only high

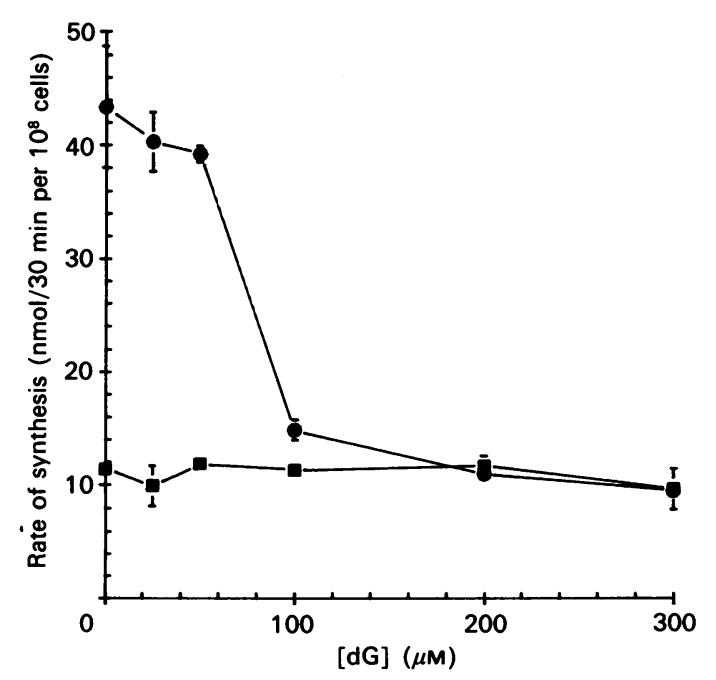

Fig. 2. Effects of dG on the rates of DNA and RNA synthesis in dGuo-L cells

dGuo-L cells were incubated for $4 \mathrm{~h}$ with $10 \mu \mathrm{M}$-mycophenolic acid and $200 \mu \mathrm{M}$-Gua together with $1 \mu \mathrm{Ci}$ each of $\left[{ }^{14} \mathrm{C}\right] \mathrm{Gua},\left[{ }^{3} \mathrm{H}\right] \mathrm{dG}$ and various concentrations of dG. The rates of DNA $(\boldsymbol{G})$ and RNA $(O)$ synthesis are presented as the sum of the amounts of both Gua and $\mathrm{dG}$ incorporated (calculated on the basis of the specific radioactivity of tracers in the medium). concentrations of dGTP or dATP $(2.5 \mathrm{~mm})$ inhibited $\left[{ }^{3} \mathrm{H}\right] \mathrm{UTP}$ incorporation by $20-30 \%$. Longer incubations ( $50 \mathrm{~min}$ ) resulted in no effect, or even a slight stimulation of $\left[{ }^{3} \mathrm{H}\right] \mathrm{UTP}$ incorporation by dGTP, whereas inhibition by dATP remained $30 \%$. On the other hand, the incorporation of $\left[{ }^{3} \mathrm{H}\right] \mathrm{GTP}$ was decreased by $25-35 \%$ during a $20 \mathrm{~min}$ incubation with $0.25 \mathrm{~mm}$-dGTP. Increasing concentrations of dGTP up to $2 \mathrm{~mm}$ failed to cause greater inhibition.

\section{Gel electrophoresis of cytoplasmic RNA from dGuo-L cells}

Cytoplasmic RNA species were extracted with phenol/chloroform and fractionated on an agarose/urea gel. Densitometric analysis of the photographic negative showed that the amounts of $28 \mathrm{~S}$ rRNA, $18 \mathrm{~S}$ rRNA or tRNA as percentages of total cytoplasmic RNA were unchanged by $\mathrm{dG}$ over a 4-h incubation period (results not shown). However, $350 \mu \mathrm{M}-\mathrm{dG}$ differentially depressed $\left[{ }^{3} \mathrm{H}\right.$ ] Gua incorporation into $28 \mathrm{~S}$ rRNA, $18 \mathrm{~S}$ rRNA and tRNA by $44 \%, 46 \%$ and $20 \%$ respectively (Table 2 ).

\section{Protein synthesis in dGuo-L cells}

In dGuo-L cells, the incorporation of $\left[{ }^{3} \mathrm{H}\right] \mathrm{Leu}$ into protein was also inhibited by $\mathrm{dG}$ in a dose-dependent fashion. The inhibition was more profound after longer dG exposure. For example, $100 \mu \mathrm{M}-\mathrm{dG}$ caused 20,30 and $40 \%$ falls in tracer incorporation at 4,8 and $16 \mathrm{~h}$ of incubation respectively. Comparing the time course of inhibition by $\mathrm{dG}$ of $\left[{ }^{3} \mathrm{H}\right] \mathrm{U}$ and $\left[{ }^{3} \mathrm{H}\right]$ Leu incorporation into RNA and protein respectively suggested that the RNA effect was already pronounced at earlier time points $(4 \mathrm{~h})$, whereas the inhibition of $\left[{ }^{3} \mathrm{H}\right]$ Leu incorporation was rather small at $4 \mathrm{~h}$.

\section{Table 2. Effects of $d G$ on the incorporation of $\left[{ }^{3} \mathrm{H}\right] \mathrm{Gua}$ into cytoplasmic RNAs}

dGuo- $L$ cells were incubated with various concentrations of $d G$ and $\left[{ }^{3} \mathrm{H}\right] \mathrm{Gua}$ for $4 \mathrm{~h}$. Cytoplasmic RNAs were then extracted and analysed on an agarose/urea gel. Radioactivity profiles are shown for $28 \mathrm{~S}$ rRNA, $18 \mathrm{~S}$ rRNA and tRNA. This experiment was repeated twice with similar results $(<5 \%$ variability for each species of RNA). Results are means \pm S.D., $n=4$.

\begin{tabular}{lcrccc}
\hline & \multicolumn{4}{c}{ Incorporation of $\left[{ }^{3} \mathrm{H}\right] \mathrm{Gua}(\mathrm{d} . \mathrm{p} . \mathrm{m} . / \mu \mathrm{g})$} \\
\cline { 3 - 6 } RNA & $\mathrm{dG}(\mu \mathrm{M}) \ldots$ & \multicolumn{1}{c}{0} & 50 & 100 & \multicolumn{1}{c}{350} \\
\hline 28 S rRNA & & $1120 \pm 80$ & $780 \pm 45$ & $670 \pm 40$ & $445 \pm 25$ \\
18 S rRNA & & $500 \pm 50$ & $445 \pm 20$ & $350 \pm 10$ & $250 \pm 15$ \\
tRNA & & $425 \pm 10$ & $360 \pm 35$ & $340 \pm 30$ & $330 \pm 10$
\end{tabular}




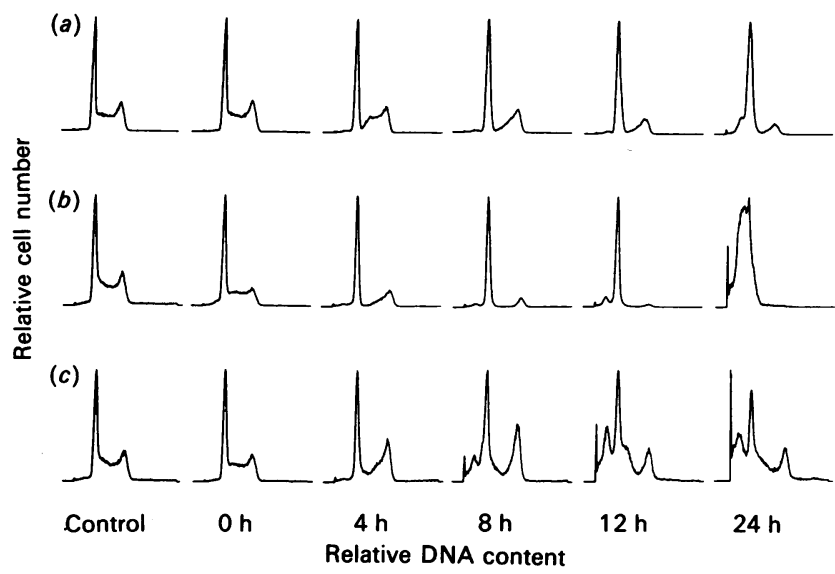

Fig. 3. DNA analysis of the cell-cycle effect of $d G$ on $S-49$ wild type (a), the PNP-negative (NSU-1, b) and the double-mutant (dGuo-L, c), cells

S-49 cells were incubated with dG, and portions of cell suspension were taken at different times. Cells were fixed with ethanol and stained with chromomycin $A_{3}$ (DNA stain) before flow-cytometric analysis. Peaks that appear before the large $G_{1}$ peak represent dead cells or cell debris with DNA content less than that of the $G_{1}$ phase cells.

\section{Effects of $\mathrm{dG}$ on cell cycle of $\mathrm{S}-\mathbf{4 9}$ cells}

After incubation with $95 \%$-growth-inhibitory concentrations (40 $\mu \mathrm{M}, 20 \mu \mathrm{M}$ and $350 \mu \mathrm{M}$ for wild-type, PNP-deficient (NSU-1) and dGuo-L cells respectively), flow cytometric analysis of total DNA content with chromomycin $A_{3}$ demonstrated a $G_{1}-S$ interface blockade in the wild-type and NSU-1 cells, but not in dGuo-L cells (Fig. 3). In contrast, dGuo-L cells accumulated slightly in the $\mathrm{G}_{2} / \mathrm{M}$ phase. Qualitatively similar changes were also observed at lower $\mathrm{dG}$ concentrations for all three cell lines. In order to investigate the mechanism of these changes, we performed dual-staining flow cytometry with BrdU and propidium iodide (Fig. 4). With dGuo-L cells, the progression of high-intensity green fluorescence (anti-BrdU antibody) that moved from $S$ phase towards $G_{2} / M$ phase (Fig. $4 a$, parts a, $\mathrm{f}-\mathrm{g}$ ) and finally back to $\mathrm{G}_{1}$-phase of the cell cycle (Fig. $4 a, \mathrm{~h}-\mathrm{i}$ ) was largely unchanged by $\mathrm{dG}$ as compared with the control (Fig.4, a-e).

On the other hand, upon dG treatment of PNP-deficient mutant NSU-1 cells (Fig. $4 b$ ) and of S-49 wild-type cells (results not shown), BrdU-labelled S-phase cells continued cycling through $\mathrm{G}_{2} / \mathrm{M}$-phase, appeared back in $\mathrm{G}_{1}$-phase, and were blocked at the $\mathrm{G}_{1}-\mathrm{S}$ interface for at least $12 \mathrm{~h}$ (Fig. $4 b, \mathrm{a}, \mathrm{f}-\mathrm{i}$ ). The slight accumulation of dGuo-L cells in $G_{2} / M$ (Fig. 3) first suggested a possible $\mathrm{M}$-phase blockade, since the assembly of tubulin into the mitotic apparatus requires GTP binding to tubulin subunits which might be interfered with by dGTP [28]. Quantitative analysis of the percentage of BrdU-labelled cells in each phase over time, however, gave superimposable plots of the rates of cell cycle progression. The mean $T_{\mathrm{s}}$ (DNA synthesis time [23]) for dG-treated and control dGuo-L cells was 8.09 and $8.10 \mathrm{~h}$ respectively. Therefore the small accumulation of the $\mathrm{G}_{2} / \mathrm{M}$ peak did not represent a $\mathrm{G}_{2} / \mathrm{M}$ blockade. Rather, the larger than normal $G_{2} / M$ peak could result from faster cell death occurring in $\mathrm{G}_{1}$ - or S-phase cells.

\section{DISCUSSION}

We have compared the effects of $\mathrm{dG}$ on a double-mutant mouse T-lymphoma cell line, dGuo-L, which is PNP-deficient and has an altered RR (partially resistant to dGTP regulation), compared with wild-type S-49 cells from which the RR hypothesis was derived [5], and with another mutant cell line, NSU-1, with PNP deficiency only.

New insights into the cytotoxic mechanism of $d G$ by $R R$ inhibition were gained with the combined use of tracer incorporation into DNA and analysis of cell cycle progression of S-49 wild-type and PNP-deficient (NSU-1) cells. Although dG decreased tracer incorporation into DNA, the effect was rather modest over at least the first $4 \mathrm{~h}$ even in the presence of toxic $\mathrm{dG}$ concentrations. Flow-cytometric DNA analysis revealed that the cell cycle was rapidly blocked at the $G_{1}-S$ interface and the $S$ phase cells were progressively depleted (Fig. 3). The decreasing fraction of S-phase cells paralleled the observed progressive decrease of tracer incorporation into DNA over time. These results when combined indicate that DNA synthesis in the remaining S-phase cells was affected by $\mathrm{dG}$ only marginally or not at all. This conclusion was confirmed with the anti-BrdU antibody flow-cytometric analysis of cell-cycle progression: Sphase cells continued to progress through $S$ and $G_{2} / M$ into $G_{1}-$ phase even in the presence of high concentrations of dG (Fig. 4). In contrast, no $G_{1}-S$ interface block was observed in the double mutant, dGuo-L, and the cells cycled normally through the cell cycle, which indicated that $R R$ inhibition was not involved in $\mathrm{dG}$ toxicity against the double mutant.

In view of the strong previous evidence that $\mathrm{dG}$ toxicity in the S-49 wild type and NSU-1 cells is associated with feedback inhibition of RR by dGTP [5], the paradoxical failure of dG to inhibit DNA synthesis in S-phase cells needed to be resolved. The dramatic differences in dGTP accumulation in $G_{1}$ - and S-phase cells can resolve this paradox. $\mathrm{G}_{1}$-phase NSU-1 and dGuo-L cells slowly and extensively accumulate dGTP (for kinetics see [25]), whereas S-phase cells show a much faster turnover rate because of ongoing DNA synthesis, and hence accumulate much less dGTP from dG. Further, we have previously shown that the direct synthesis of dGTP from $\mathrm{dG}$ has limited capacity relative to dGTP utilization for DNA synthesis [25]. The drastically lower dGTP accumulation in S-phase compared with $G_{1}$-phase cells is expected to mitigate $\mathrm{dG}$ effects specifically in S-phase cells. Therefore the lack of toxic dGTP accumulation in S-phase cells accounts for the continuing DNA synthesis in S-49 cells already in S-phase, and the increasing depression of tracer incorporation into DNA over time closely parallels the gradual depletion of Sphase cells (Figs. 3 and 4). On the other hand, the activation of RR during the $G_{1}-S$ transition [26] should be blocked by preexisting high dGTP levels, keeping the cells in $G_{1}$-phase. Hence the double mutant, dGuo-L, with impaired feedback inhibition of $R R$, readily passes through the $G_{1}-S$ interface into S-phase, where dGTP levels rapidly drop. The continuous escape of dGuo-L cells into S-phase can therefore account for its relative resistance against $\mathrm{dG}$ toxicity. Furthermore, one can now propose the more general hypothesis that inhibition of RR by dGTP merely serves to keep cells in the sensitive $G_{1}$-phase where other mechanisms of $\mathrm{dGTP} / \mathrm{dG}$ toxicity may be operative.

The cell cycle effects of $d A$, i.e. $a_{1}-S$ interface block, are very similar to those of dG. We have already documented that $\left[{ }^{3} \mathrm{H}\right] \mathrm{dA}$ [in combination with erythro-9-(2-hydroxyl-3-nonyl)adenine (EHNA), an adenosine deaminase inhibitor] also accumulates slowly in the dATP of $G_{1}$ - but not S-phase cells of the S-49 cell lines [28]. Hence dG and dA may both exert their toxicity in the $G_{1}$-phase, subsequent to a $G_{1}-S$ interface blockade mediated by $R R$ inhibition. In contrast, very different effects on cell cycle progression are observed with other agents that block RR, e.g. thymidine and hydroxyurea $[29,30]$ which freeze cells in the Sphase. Thymidine rapidly equilibrates with the dTTP pool [27], and hydroxyurea immediately inhibits $R R$, thereby preventing further DNA synthesis in S-phase cells. 


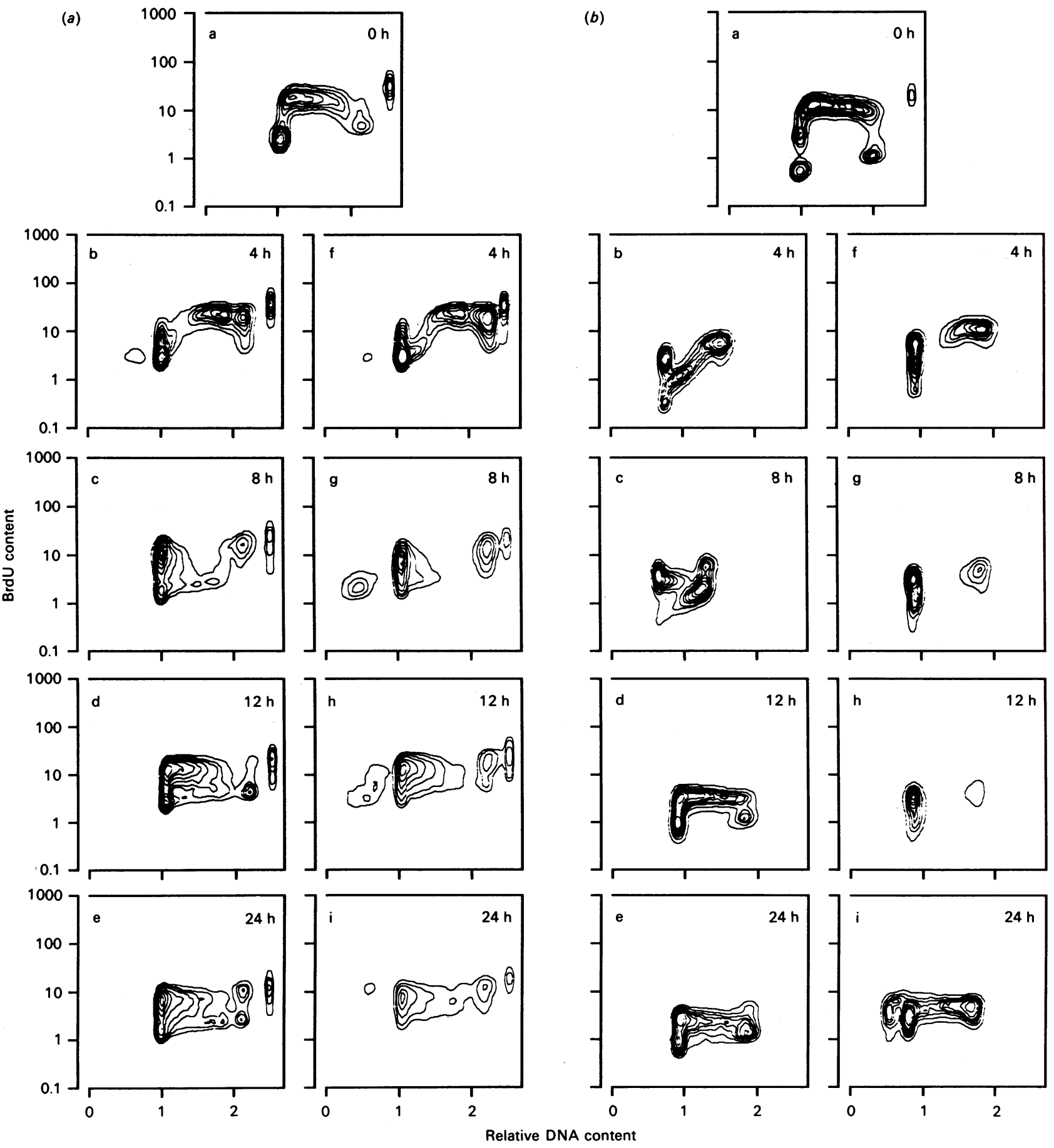

Fig. 4. Cell-cycle effects of $\mathrm{dG}$ on $\mathrm{S}-49$ cells by dual-staining flow cytometric analysis

Bivariate DNA/BrdU distributions of S- 49 cells were measured at different time intervals after 30 min exposure to $10 \mu \mathrm{M}$-BrdU and addition of $\mathrm{dG}$ immediately afterwards. The intensity of both the green fluorescence (from anti-BrdU antibody, $x$-axis) and the red fluorescence (from propidium iodide, $y$-axis) is expressed on a logarithmic scale. (a) Progression of control (a-e) and dG (350 $\mu \mathrm{M})$-treated (f-i) dGuo-L cells through the cell cycle. (b) Cell cycle of control $(\mathrm{a}-\mathrm{e})$ and dG $(20 \mu \mathrm{M})$-treated $(\mathrm{f}-\mathrm{i})$ PNP negative mutant S49 cells. Parallel results obtained with S-49 wildtype cells were identical to those of the PNP-negative mutant.

Our extensive studies with several tracers to measure RNA synthesis clearly indicate an early inhibition of RNA synthesis by $\mathrm{dG}$, followed by an inhibition of $\left[{ }^{3} \mathrm{H}\right] \mathrm{Leu}$ incorporation into proteins. The mechanisms by which $\mathrm{dG}$ affects RNA synthesis and metabolism, as shown in this study, remain to be investigated in detail, but they appear to be unrelated to competition between dGTP and GTP for RNA polymerases.

This study was supported by Grant CA 27866 from National Cancer Institute, National Institutes of Health. 


\section{REFERENCES}

1. Giblett, E. R., Ammann, A. J., Wara, D. W., Sandman, R. \& Diamond, L. K. (1975) Lancet i, 1010-1013

2. Stoop, J. W., Zegers, B. J. M., Hendrikx, G. F. M., Siegenbeek van Heukelom, L. H., Staal, G. E. J., de Bree, P. K., Wadman, S. K. \& Ballieux, R. E. (1977) N. Engl. J. Med. 296, 651-655

3. Giblett, E. R., Anderson, J. E., Cohen, F., Pollara, B. \& Meuwissen, H. J. (1972) Lancet ii, 1067-1069

4. Mitchell, B. S. \& Kelley, W. N. (1980) Ann. Intern. Med. 92, 826-831

5. Martin, D. W., Jr. \& Gelfand, E. W. (1981) Annu. Rev. Biochem. 50, 845-877

6. Chan, T.-S. (1978) Cell 14, 523-530

7. Cohen, A., Gudas, L. J., Ammann, A. J., Staal, G. E. \& Martin, D. W., Jr. (1978) J. Clin. Invest. 61, 1405-1409

8. Wilson, J. M., Mitchell, B. S., Dadonna, P. E. \& Kelley, W. N. (1979) J. Clin. Invest. 64, 1475-1484

9. Mann, G. J. \& Fox, R. M. (1987) J. Clin Invest. 78, 1261-1269

10. Carson, D. A., Kaye, J. \& Seegmiller, J. E. (1977) Proc. Natl. Acad. Sci. U.S.A. 74, 5677-5681

11. Gelfand, E. W., Lee, J. J. \& Dosch, H.-M. (1979) Proc. Natl. Acad. Sci. U.S.A. 76, 1998-2002

12. Stoeckler, J. D. (1984) in Developments in Cancer Chemotherapy (Glazer, R. I., ed.), pp. 35-60, CRC Press, Boca Raton, FL

13. Martineau, R. \& Willemot, J. (1983) Immunopharmacology 6 , 289-302

14. Dosch, H. M., Mansour, A., Cohen, A., Shore, A. \& Gelfand, E. W (1980) Nature (London) 285, 494-496

15. Bril, H., van den Akker, T. W., Molendijk-Lok, B. D., Bianchi, A. T. \& Benner, R. (1984) J. Immunol. 132, 599-604
16. Spaapen, L. J. M., Rijkers, G. T., Staal, G. E. J., Rijksen, G., Wadman, S. K., Stoop, J. W. \& Zegers, B. J. M. (1984) J. Immunol. 132, 2311-2317

17. Carson, D. A., Wasson, D. B., Lakow, E. \& Kamatani, N. (1982) Proc. Natl. Acad. Sci. U.S.A. 79, 3848-3852

18. Ullman, B., Gudas, L. J., Clift, S. M. \& Martin, D. W., Jr. (1979) Proc. Natl. Acad. Sci. U.S.A. 76, 1074-1078

19. Pogolotti, A. L., Jr. \& Santi, D. V. (1982) Anal. Biochem. 126, 335-345

20. Nguyen, B. T. \& Sadée, W. (1986) Biochem. J. 234, 263-269

21. Crissman, H. A. \& Tolby, R. A. (1974) Science 84, 1297-1298

22. Dolbeare, F., Gratzner, H., Pallavicini, M. G. \& Gary, J. W. (1983) Proc. Natl. Acad. Sci. U.S.A. 80, 5573-5577

23. Begg, A. C., McNally, N. J., Shrieve, D. C. \& Karcher, H. (1985) Cytometry 6, 620-626

24. Pawlak, K., Lawi-Berger, C. \& Sadée, W. (1986) Biochem. J. 238, 13-21

25. Duan, D.-S. \& Sadée, W. (1988) Biochem. J. 255, 1045-1048

26. Albert, D. A. \& Gudas, L. J. (1985) J. Biol. Chem. 260, 679-684

27. Maybaum, J., Cohen, M. B. \& Sadée, W. (1981) J. Biol. Chem. 256, 2126-2130

28. Hamel, E., del Campo, A. A., Lustbader, J. \& Lin, C. M. (1983) Biochemistry 22, 1271-1279

29. Duan, D.-S. \& Sadée, W. (1987) Cancer Res. 47, 4047-4051

30. Fox, R. M., Kefford, R. F., Tripp, E. H. \& Taylor, I. W. (1981) Cancer Res. 41, 5141-5150

31. Faller, J., Palella, T. D., Dean, P. \& Fox, I. H. (1984) Metabolism 33, 369-374

Received 20 November 1989/13 February 1990; accepted 28 February 1990 